\title{
Methylibium aquaticum sp. nov., a betaproteobacterium isolated from a eutrophic freshwater pond
}

\author{
Jaeho Song and Jang-Cheon Cho \\ Division of Biology and Ocean Sciences, Inha University, Incheon 402-751, Republic of Korea
}

Correspondence

Jang-Cheon Cho

chojc@inha.ac.kr

\begin{abstract}
A freshwater bacterium, designated IMCC $1728^{\top}$, was isolated from a eutrophic pond. The strain was Gram-negative, chemoheterotrophic and facultatively aerobic, forming non-motile rods that contained poly- $\beta$-hydroxybutyrate granules. Based on 16S rRNA gene sequence comparisons, the most closely related species to strain IMCC1728 ${ }^{\top}$ was Methylibium petroleiphilum $(97.0 \%$ similarity). Phylogenetic trees generated using $16 \mathrm{~S}$ rRNA gene sequences showed that this isolate formed an independent phyletic line of the genus Methylibium clade of the class Betaproteobacteria. The DNA G $+\mathrm{C}$ content of the strain was $66.2 \pm 0.4 \mathrm{~mol} \%$. The predominant cellular fatty acid constituents were $\mathrm{C}_{16: 1} \omega 7 \mathrm{c}$ and/or iso- $\mathrm{C}_{15: 0} 2-\mathrm{OH}(43.1 \%), \mathrm{C}_{16: 0}(20.3 \%)$, $\mathrm{C}_{12: 0}(13.4 \%)$ and $\mathrm{C}_{10: 0} 3-\mathrm{OH}(7.3 \%)$. The strain contained $\mathrm{Q}-8$ as the predominant ubiquinone. Several phenotypic characteristics, including flagellation, temperature range for growth and carbon source utilization patterns, differentiated strain IMCC $1728^{\top}$ from species of the genus Methylibium. Therefore, it is proposed that strain IMCC1728 ${ }^{\top}$ represents a novel species, Methylibium aquaticum sp. nov. The type strain is IMCC1728 ${ }^{\top}$ (=KCCM $42364^{\top}=$ NBRC $102349^{\top}$ ).
\end{abstract}

The genus Methylibium of the Sphaerotilus-Leptothrix group (Spring, 2002) in the class Betaproteobacteria was recently established by Nakatsu et al. (2006) and the genus currently contains one species, Methylibium petroleiphilum. M. petroleiphilum was isolated from a compost biofilter. This species is a Gram-negative, rod-shaped, facultative methylotrophic bacterium that is motile with one polar flagellum and can degrade methyl tert-butyl ether. Characterization of strain IMCC $1728^{\mathrm{T}}$, a novel species of the genus Methylibium isolated from a eutrophic freshwater pond, is described in this report.

Strain IMCC $1728^{\mathrm{T}}$ was isolated from an artificial freshwater pond located inside Inha University (Incheon, Korea) by using a standard dilution plating method on R2A agar (Reasoner \& Geldreich, 1985) diluted in distilled water $(1: 10, \mathrm{v} / \mathrm{v})$ after aerobic incubation at $20{ }^{\circ} \mathrm{C}$ for 5 days. After determination of optimum medium and temperature for growth, bacterial cultures were routinely maintained on $\mathrm{R} 2 \mathrm{~A}$ agar at $30{ }^{\circ} \mathrm{C}$.

Methods for DNA extraction, PCR and 16S rRNA gene sequencing have been described in a previous study (Cho \& Giovannoni, 2003). The resultant almost-complete $16 \mathrm{~S}$

Abbreviations: $\mathrm{PHB}$, poly- $\beta$-hydroxybutyrate; TEM, transmission electron microscopy.

The GenBank/EMBL/DDBJ accession number for the $16 \mathrm{~S}$ rRNA gene sequence of strain IMCC $1728^{\top}$ is DQ664244.
rRNA gene sequence (1484 bp) of strain IMCC $1728^{\mathrm{T}}$ was aligned with sequences of nearest neighbours using the ARB software package (Ludwig et al., 2004) and 16S rRNA gene sequence similarities were calculated based on this alignment. Unambiguously aligned $1294 \mathrm{nt}$ positions, determined from 13 betaproteobacterial 16S rRNA gene sequences, were used for phylogenetic analyses in PAUP ${ }^{*}$ 4.0 beta 10 (Swofford, 2002). Phylogenetic trees were generated by neighbour-joining (Saitou \& Nei, 1987) with the Jukes-Cantor distance (Jukes \& Cantor, 1969), maximum-parsimony (Fitch, 1971) and maximumlikelihood (Felsenstein, 1981) methods. Robustness of the neighbour-joining and maximum-parsimony trees was confirmed by bootstrap analyses based on 100 resamplings of the sequences. Preliminary sequence comparison with $16 \mathrm{~S}$ rRNA gene sequences deposited in GenBank and RDPII (Cole et al., 2005) indicated that strain IMCC $1728^{\mathrm{T}}$ was closely related to members of the genus Methylibium in the class Betaproteobacteria. Strain IMCC $1728^{\mathrm{T}}$ showed highest 16S rRNA gene sequence similarity to $M$. petroleiphilum ATCC BAA- $1232^{\mathrm{T}}(97.0 \%)$, followed by Ideonella dechloratans ATCC $51718^{\mathrm{T}}(96.1 \%)$, Aquabacterium commune ATCC BAA-209 ${ }^{\mathrm{T}}(95.7 \%)$ and Aquabacterium parvum ATCC BAA- $208^{\mathrm{T}}(95.6 \%)$. In all phylogenetic trees generated in this study (Fig. 1), strain IMCC1728 ${ }^{\mathrm{T}}$, uncultured groundwater bacterium 300A-D08 (GenBank accession no. AY662010; Fields et al., 2005) and uncultured ironoxidizing lagoon bacterium 015 (GenBank accession 


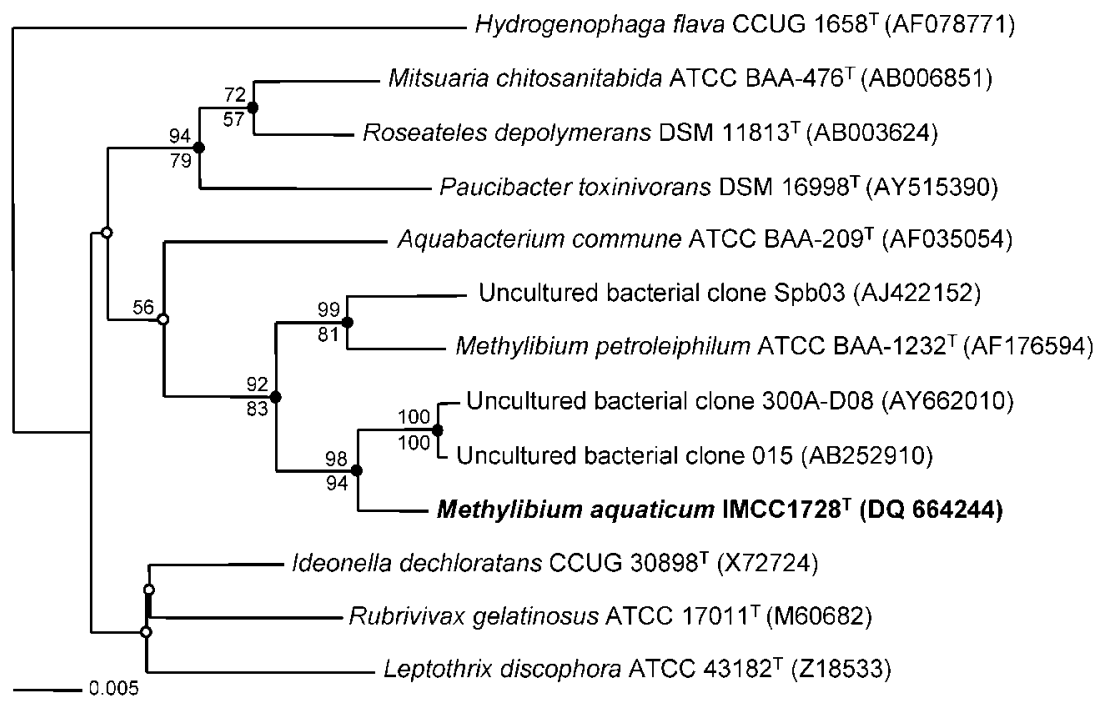

Fig. 1. Neighbour-joining phylogenetic tree based on 16S rRNA gene sequences, showing the relationship between strain IMCC $1728^{\top}$ and its relatives. Bootstrap percentages (above $50 \%$ ) from both neighbourjoining (above nodes) and maximum-parsimony (below nodes) are shown. Nodes recovered reproducibly by all treeing methods (filled circles) or by two treeing methods (open circles) are indicated. Bar, 0.005 substitutions per nucleotide position.

no. AB252910) formed a monophyletic clade. This clade was anchored to the clade containing $M$. petroleiphilum with high bootstrap values ( $92 \%$ in neighbour-joining and $83 \%$ in maximum-parsimony trees), indicating that strain IMCC $1728^{\mathrm{T}}$ represents a novel species of the genus Methylibium.

Growth at various temperatures $\left(4-42{ }^{\circ} \mathrm{C}\right)$ and optimum growth temperature were determined on $\mathrm{R} 2 \mathrm{~A}$ agar. In further phenotypic and chemotaxonomic tests, strain IMCC $1728^{\mathrm{T}}$ was routinely maintained at $30{ }^{\circ} \mathrm{C}$ on $\mathrm{R} 2 \mathrm{~A}$ agar, unless otherwise noted. The $\mathrm{pH}$ range and optimum for growth were examined at $\mathrm{pH} 4.0-12.0$. The requirement of $\mathrm{NaCl}$ and the optimum for growth were determined in R2A agar supplemented with $0-15 \%(\mathrm{w} / \mathrm{v})$ $\mathrm{NaCl}$. Cell morphology was observed under a phasecontrast microscope (Nikon 80i) and by transmission electron microscopy (TEM) (CM200; Philips). TEM was also used to determine the presence of flagella and intracellular granules. The presence of poly- $\beta$-hydroxybutyrate (PHB) granules was confirmed using the Nile Blue A staining method described by Ostle \& Holt (1982). Colony morphology, size and colour were examined from cultures grown for 3 days. Motility was tested by using wet mounts of exponential-phase cells. Anaerobic growth was tested employing Anaerocult C mini (EM science) and AnaeroPack Anaero (Mitsubishi Gas Chemical). Catalase activity was determined by the reaction of $3 \%$ hydrogen peroxide on fresh colonies and the oxidase test was performed using Kovacs' solution (Kovacs, 1956). Other biochemical tests were carried out by using the API 20NE and API ZYM (both bioMérieux) systems according to the manufacturer's instructions. Sole carbon source utilization tests were performed using custom-made 48 -well microplates. Approximately $1.4 \times 10^{4}$ cells ml $^{-1}$ in PBS ( $\mathrm{pH}$ 7.4) were inoculated into each well, which contained one of 47 different carbon compounds (list of compounds is given in the species description) at a final concentration of $0.2 \%$ $(\mathrm{w} / \mathrm{v}$ or $\mathrm{v} / \mathrm{v})$. After incubation of the microplates for 1 week at $30{ }^{\circ} \mathrm{C}$, cellular growth and purity were checked as described previously (Cho \& Giovannoni, 2003). Susceptibility to 10 different antimicrobial agents (list given in the species description) was determined using the diffusion plate method (Jorgensen et al., 1999). The DNA $\mathrm{G}+\mathrm{C}$ content was analysed by using HPLC according to Mesbah et al. (1989) with a Discovery C18 column (5 $\mu \mathrm{m}$, $15 \mathrm{~cm} \times 4.6 \mathrm{~mm}$; Supelco). Cellular fatty acid methyl esters were collected from fresh cultures grown on R2A agar at $30{ }^{\circ} \mathrm{C}$ for 4 days and analysed according to the instructions of the Microbial Identification System (MIDI) by the Korean Culture Center of Micro-organisms (KCCM). Respiratory quinone content was determined by using reverse-phase HPLC analysis (Komagata \& Suzuki, 1987) by the KCCM.

In summary, cells of strain IMCC $1728^{\mathrm{T}}$ were Gramnegative, chemoheterotrophic, facultatively aerobic, nonmotile, short rods that contained PHB granules (Fig. 2). Detailed results of phenotypic and biochemical tests are given in the species description and Table 1. As shown in Table 1, strain IMCC $1728^{\mathrm{T}}$ shared similar characteristics with $M$. petroleiphilum ATCC BAA- $1232^{\mathrm{T}}$, including DNA $\mathrm{G}+\mathrm{C}$ content, major fatty acid constituents, Q-8 as the major quinone type and the presence of $\mathrm{PHB}$ granules. However, differences in several phenotypic properties (Table 1) together with a phylogenetically distinct relationship (Fig. 1) between the two strains indicate that strain IMCC $1728^{\mathrm{T}}$ represents a novel species of the genus Methylibium, for which the name Methylibium aquaticum sp. nov. is proposed.

\section{Description of Methylibium aquaticum sp. nov.}

Methylibium aquaticum (a.qua'ti.cum. L. neut. adj. aquaticum living in water, aquatic).

Gram-negative and non-motile. Cells are short rods (0.8$1.9 \times 0.4-0.7 \mu \mathrm{m})$. After 4 days incubation, colonies on R2A agar are circular, umbonate, beige-milkish, smooth 


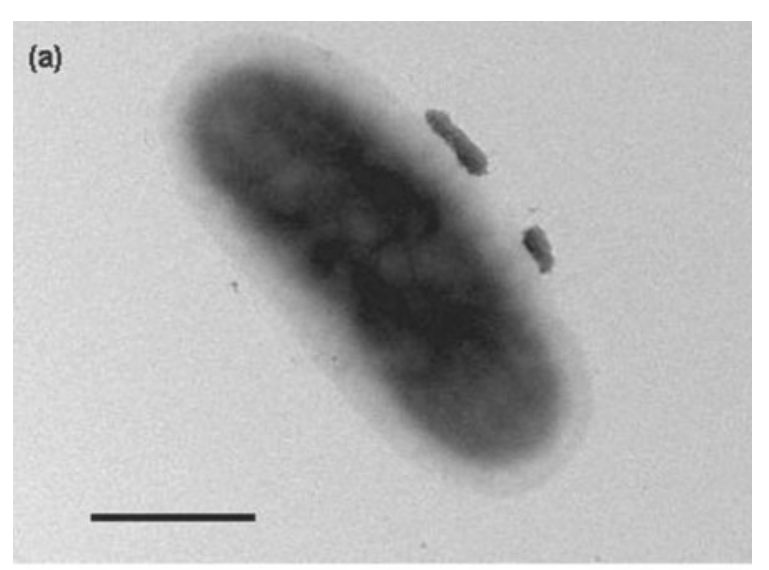

(b)

Fig. 2. (a, b) Negatively stained TEMs of cells of strain IMCC 1728 ${ }^{\top}$. Arrows in panel (b) indicate PHB granules. Bars, $0.5 \mu \mathrm{m}$

with entire margin and $0.5-2.0 \mathrm{~mm}$ in diameter. Growth occurs at $15-42{ }^{\circ} \mathrm{C}$ and $\mathrm{pH} 6-10$ and in $0-1 \% \mathrm{NaCl}$; optimal growth is observed at $30^{\circ} \mathrm{C}, \mathrm{pH} 7.0$ and in the absence of $\mathrm{NaCl}$. Contains $\mathrm{PHB}$ granules. Chemoheterotrophic and facultatively aerobic. Anaerobic growth is much slower than aerobic growth. Catalase-negative and oxidasepositive. Gelatinase activity and aesculin hydrolysis are weakly positive. Nitrate reduction, indole production, glucose fermentation, arginine dihydrolase, urease and $\beta$ galactosidase are negative (API 20NE). Using the API ZYM system, alkaline phosphatase and leucine arylamidase activities are positive; esterase (C4), esterase lipase (C8), lipase (C14), valine arylamidase, cystine arylamidase, trypsin, $\alpha$-chymotrypsin, acid phosphatase, naphthol-ASBI-phosphohydrolase, $\alpha$-galactosidase, $\beta$-galactosidase, $\beta$-glucuronidase, $\alpha$-glucosidase, $\beta$-glucosidase, $N$-acetyl- $\beta$ glucosaminidase, $\alpha$-mannosidase and $\alpha$-fucosidase activities are negative. Of the 47 different carbon sources in the custom-made 48-well plate assay, the following carbon substrates are utilized: methanol, glycerol, D-ribose, D-galactose, $\mathrm{N}$-acetyl-D-glucosamine, rhamnose, adonitol, D-xylitol, gluconic acid, malonic acid, propionic acid, L-alanine, L-arginine, L-histidine, L-proline and L-serine.
Table 1. Characteristics that differentiate strain $I M C C 1728^{\top}$ from Methylibium petroleiphilum ATCC BAA-1232 ${ }^{\top}$

Data from this study and Nakatsu et al. (2006). +, Positive; -, negative; $\mathrm{w}$, weakly positive. Both strains were positive for oxidase activity, anaerobic growth, presence of $\mathrm{PHB}$, and utilization of methanol and alanine. Both strains were negative for catalase activity, indole production, and utilization of arabinose, xylose, melibiose, sucrose, glycine, glucose and citric acid. The major quinone of both strains was Q-8.

\begin{tabular}{|c|c|c|}
\hline Characteristic & $\begin{array}{l}\text { M. aquaticum } \\
\text { IMCC } 1728^{\mathrm{T}}\end{array}$ & $\begin{array}{l}\text { M. petroleiphilum } \\
\text { ATCC BAA-1232 }\end{array}$ \\
\hline Isolation source & Eutrophic freshwater & Compost biofilter \\
\hline Flagellation & - & + \\
\hline Growth at $37{ }^{\circ} \mathrm{C}$ & + & - \\
\hline Nitrate reduction & - & + \\
\hline \multicolumn{3}{|l|}{ Hydrolysis of: } \\
\hline Urea & - & + \\
\hline Aesculin & $\mathrm{w}$ & - \\
\hline Gelatin & $\mathrm{w}$ & - \\
\hline \multicolumn{3}{|l|}{ Carbon utilization: } \\
\hline Ethanol & - & + \\
\hline Rhamnose & + & - \\
\hline Pyruvic acid & - & + \\
\hline \multicolumn{3}{|l|}{ Major fatty acid (\%):* } \\
\hline $\mathrm{C}_{16: 1} \omega 7 c$ & $43.1 \dagger$ & 43.4 \\
\hline $\mathrm{C}_{16: 0}$ & 20.3 & 39.0 \\
\hline $\mathrm{C}_{12: 0}$ & 13.4 & 4.7 \\
\hline $\mathrm{C}_{10: 0} 3-\mathrm{OH}$ & 7.3 & 2.9 \\
\hline cyclo $\mathrm{C}_{17: 0}$ & 4.2 & - \\
\hline $\mathrm{C}_{18: 1} \omega 7 c$ & 1.5 & 7.6 \\
\hline $\begin{array}{l}\text { DNA G }+\mathrm{C} \text { content } \\
(\mathrm{mol} \%)\end{array}$ & 66.2 & 69 \\
\hline
\end{tabular}

${ }^{*}$ The major fatty acid proportions of M. petroleiphilum were graciously provided by Cindy $\mathrm{H}$. Nakatsu.

$\nmid \mathrm{C}_{16: 1} \omega 7 c$ and/or iso- $\mathrm{C}_{15: 0} 2-\mathrm{OH}$.

However, methylamine, ethanol, DL-glyceraldehyde, D-arabinose, D-xylose, D-fructose, D-glucosamine, D-glucose, D-mannose, D-cellobiose, D-lactose, maltose, melibiose, sucrose, trehalose, D-melezitose, D-raffinose, arabitol, D-mannitol, myo-inositol, D-sorbitol, citric acid, glucuronic acid, itaconic acid, pyruvic acid, succinic acid, L-glutamic acid, L-glycine, L-leucine, L-lysine and L-ornithine are not utilized. Susceptible to ( $\mu \mathrm{g})$ chloramphenicol (25), erythromycin (15), streptomycin (10), gentamicin (10), kanamycin (30), penicillin G (10) and vancomycin (30). Resistant to $(\mu \mathrm{g})$ ampicillin (10), rifampicin (50) and tetracycline (30). The cellular fatty acids are composed of $\mathrm{C}_{16: 1} \omega 7 c$ and/or iso- $\mathrm{C}_{15: 0} 2-\mathrm{OH}(43.1 \%), \mathrm{C}_{16: 0}(20.3 \%)$, $\mathrm{C}_{12: 0}(13.4 \%), \mathrm{C}_{10: 0} 3-\mathrm{OH}(7.3 \%)$, cyclo $\mathrm{C}_{17: 0}(4.2 \%)$, $\mathrm{C}_{18: 1} \omega 7 c(1.5 \%), \mathrm{C}_{15: 0} \quad(1.4 \%), \mathrm{C}_{17: 0} \quad(1.4 \%), \mathrm{C}_{14: 0}$ $(1.0 \%), \mathrm{C}_{15: 1} \omega 6 c(0.9 \%), \mathrm{C}_{18: 0}(0.8 \%)$ and 11-methyl $\mathrm{C}_{18: 1} \omega 7 c(0.6 \%)$. The major quinone type is Q- 8 . The DNA G $+\mathrm{C}$ content of the type strain is $66.2 \pm 0.4 \mathrm{~mol} \%$. 
The type strain, IMCC $1728^{\mathrm{T}}\left(=\mathrm{KCCM} 42364^{\mathrm{T}}=\mathrm{NBRC}\right.$ $102349^{\mathrm{T}}$ ), was isolated from an artificial freshwater pond located inside Inha University, Incheon, Korea.

\section{Acknowledgements}

We are grateful to Dr Cindy H. Nakatsu for sharing with us the fatty acid proportions of $M$. petroleiphilum ATCC BAA-1232 ${ }^{\mathrm{T}}$. This study was supported by an Inha University Research Grant.

\section{References}

Cho, J.-C. \& Giovannoni, S. J. (2003). Parvularcula bermudensis gen. nov., sp. nov., a marine bacterium that forms a deep branch in the $\alpha$-Proteobacteria. Int J Syst Evol Microbiol 53, 1031-1036.

Cole, J. R., Chai, B., Farris, R. J., Wang, Q., Kulam, S. A., McGarrell, D. M., Garrity, G. M. \& Tiedje, J. M. (2005). The Ribosomal Database Project (RDP-II): sequences and tools for high-throughput rRNA analysis. Nucleic Acids Res 33, D294-D296.

Felsenstein, J. (1981). Evolutionary trees from DNA sequences: a maximum likelihood approach. J Mol Evol 17, 368-376.

Fields, M. W., Yan, T., Rhee, S.-K., Carroll, S. L., Jardine, P. M., Watson, D. B., Criddle, C. S. \& Zhou, J. (2005). Impacts on microbial communities and cultivable isolates from groundwater contaminated with high levels of nitric acid-uranium waste. FEMS Microbiol Ecol 53, 417-428.

Fitch, W. M. (1971). Toward defining the course of evolution: minimum change for a specific tree topology. Syst Zool 20, 406-416.

Jorgensen, J. H., Turnidge, J. D. \& Washington, J. A. (1999). Antibacterial susceptibility tests: dilution and disk diffusion methods. In Manual of Clinical Microbiology, 7th edn, pp. 1526-1543. Edited by P. R. Murray, E. J. Baron, M. A. Pfaller, F. C. Tenover \& R. H. Yolken. Washington, DC: American Society for Microbiology.
Jukes, T. H. \& Cantor, C. R. (1969). Evolution of protein molecules. In Mammalian Protein Metabolism, pp. 21-132. Edited by H. N. Munro. New York: Academic Press.

Komagata, K. \& Suzuki, K. (1987). Lipid and cell-wall analysis in bacterial systematics. Methods Microbiol 19, 161-207.

Kovacs, N. (1956). Identification of Pseudomonas pyocyanea by the oxidase reaction. Nature 178, 703.

Ludwig, W., Strunk, O., Westram, R., Richter, L., Meier, H., Yadhukumar, Buchner, A., Lai, T., Steppi, S. \& other authors (2004). ARB: a software environment for sequence data. Nucleic Acids Res 32, 1363-1371.

Mesbah, M., Premachandran, U. \& Whitman, W. B. (1989). Precise measurement of the $\mathrm{G}+\mathrm{C}$ content of deoxyribonucleic acid by highperformance liquid chromatography. Int J Syst Bacteriol 39, 159-167.

Nakatsu, C. H., Hristova, K., Hanada, S., Meng, X. Y., Hanson, J. R., Scow, K. M. \& Kamagata, Y. (2006). Methylibium petroleiphilum gen. nov., sp. nov., a novel methyl tert-butyl ether-degrading methylotroph of the Betaproteobacteria. Int J Syst Evol Microbiol 56, 983-989.

Ostle, A. G. \& Holt, J. G. (1982). Nile blue A as a fluorescent stain for poly- $\beta$-hydroxybutyrate. Appl Environ Microbiol 44, 238-241.

Reasoner, D. J. \& Geldreich, E. E. (1985). A new medium for the enumeration and subculture of bacteria from potable water. Appl Environ Microbiol 49, 1-7.

Saitou, N. \& Nei, M. (1987). The neighbor-joining method: a new method for reconstructing phylogenetic trees. Mol Biol Evol 4, 406-425.

Spring, S. (2002). The genera Leptothrix and Sphaerotilus. In The Prokaryotes: a Handbook on the Biology of Bacteria, 3rd edn, vol. 5, pp. 758-777. Edited by M. Dworkin, K. H. Schleifer \& E. Stackebrandt. New York: Springer.

Swofford, D. L. (2002). PAUP ${ }^{*}$ : Phylogenetic analysis using parsimony (*and other methods). Sunderland, MA: Sinauer Associates. 